\title{
Pre-service Social Sciences Teachers' Reflections on a Teacher Preparation Program
}

\author{
Munje Paul Nwati \\ University of the Free State, South Africa \\ https:// orcid.org/0000-0002-7948-9704 \\ Jita Thuthukile \\ Faculty of Education, University of the Free State, South Africa \\ https:// orcid.org/0000-0002-1173-5251
}

\begin{abstract}
The need for quality education in South Africa and beyond encourages research that interrogates the preparation of pre-service teachers and their ability to teach in the classroom after graduation. This qualitative paper focuses on the reflections of final year pre-service Social Sciences teachers in a South African public university. Gibbs' reflective cycle is used as a lens. We used open-ended questions to gather data from 19 pre-service Social Sciences teachers to explore their preparedness and readiness to teach in future. The research process constituted two phases. Phase one was implemented from 10 February 2020 to 9 March 2020 and phase two occurred in July 2020. Phase two was necessitated by the negative educational implications of COVID-19. Findings indicated that the participants faced challenges pertaining to content knowledge, which was aggravated by the introduction of online learning due to COVID-19. Despite these challenges, participants remained resilient and optimistic toward the teaching profession. Deducing from their voices, we recommend clarification of content in Social Sciences core subjects of History and Geography. Balanced tuition for content knowledge and pedagogy is recommended. Ongoing professional development is needed for academic advisors concerning subject specifications and for lecturers to empower them about remote teaching, communication, and technological skills to improve teaching and learning. Regular monitoring by the teaching and learning unit in the faculty is required to identify challenges and to intervene where necessary. The varied challenges of online learning also warrant the equipping of students with the necessary resources to facilitate learning.
\end{abstract}

Keywords: content knowledge; COVID-19; online learning; pre-service teachers; Social Sciences; South Africa 


\section{Introduction}

The clamor for quality education across the globe puts the spotlight on pre-service teachers' preparedness, readiness, and ability to teach effectively upon graduation. Teacher education programs around the world aim at ensuring adequate preparation of pre-service teachers since their output is reflected through outcomes in schools where they teach (Hudson, 2011; Mkhasibe, 2018; Tatto \& Pippin, 2017). Mkhasibe (2018) noted that many pre-service teachers are unable to perform their duties as expected by the training institutions and the schools where knowledge is imparted to add value and improve learner performance and experiences. This expectation explicates the massive investment in teacher preparation globally in order to graduate quality pre-service teachers (Hudson, 2011). Interestingly, Mayer et al. (2017) supposed that the perceptions of graduate teachers represent the quality and value of the institutions that prepared them. Therefore, adequate preparation of pre-service teachers influences how they view themselves as professional teachers and the way they teach learners.

Determining the characteristics of a well-prepared pre-service teacher is a discourse on its own, however. Some scholars have argued that content-knowledge acquisition by pre-service teachers is fundamental and guarantees their preparedness and readiness to teach effectively (Mkhasibe, 2018). Seemingly, those with insufficient content knowledge are generally ill-prepared or demotivated to teach (Kenna \& Poole, 2017). This aligns with the notion of Cochran-Smith and Lytle (1999, p. 249) that "... teachers who know more teach better". Globally, teacher education programs envisage pre-service teachers who are adequately prepared holistically to effectively deliver the curriculum (Petrarca \& Bullock, 2014; Tambyah, 2008). The lack of a holistic preparation approach exposes some teacher training institutions to criticisms (Naylor et al., 2015).

According to Harte and Reitano (2015), the duration of teacher education programs in some countries makes it challenging for effective incorporation of adequate content knowledge and skills. In some instances, substantial focus is placed on pedagogical skills at the detriment of content knowledge. For example, Harte and Reitano (2015) argued that pre-service Geography teachers need to be grounded in both physical and human geography to teach Geography effectively, the lack of which will create imminent challenges. When teachers do not understand the basic concepts in Geography, there are likely to be negative repercussions on learners (Blankman et al., 2016). However, the way subjects such as Geography are taught to pre-service teachers varies globally based on contextual realities (Tatto \& Pippin, 2017). Such variances lead to the different experiences amassed by pre-service teachers globally.

The importance of content knowledge to pre-service teachers has been recognized for decades and captured succinctly by Cochran-Smith and Lytle (1999). Tatto and Pippin (2017) contended that the ability of individual teacher education programs around the world to maintain quality in their teacher preparation in various sectors is based on contextual realities, making standardization difficult to achieve. Notably, the conceptualization of what a quality teacher education 
program means is not linear (Cochran-Smith \& Lytle, 1999), although quality assurance mechanisms are visible in higher education institutions globally. This is exacerbated by the lack of a universal agreement of what constitutes content knowledge in a teacher preparation program (Harte \& Reitano, 2015), making this line of argumentation somewhat contested and fragmented. This paper emanates from impromptu discussions about pre-service teachers' readiness to teach. The varied perceptions that arose, including challenges with content knowledge in the classroom during teaching practice, made it relevant to interrogate their teacher preparation program in-depth.

\subsection{Gauging pre-service Social Sciences teachers' preparedness and readiness}

Pre-service Social Sciences teachers face challenges in terms of the requisite skills and content knowledge due to the broadness of the field. In the view of Tambyah (2008), the knowledge base of pre-service Social Sciences teachers is problematic in some teacher education programs, with the lack of relevant disciplinary knowledge for many novice Social Sciences teachers a commonality. Apparently, not enough is done in teacher education programs in many countries, including South Africa, the United States, and England, to adequately equip pre-service teachers with the necessary skills, including controversial topics which constitute an important component of teaching and learning in Social Sciences (Chikoko et al., 2011, cited in Nganga et al., 2020). In this regard, Nganga et al. (2020) argued that pre-service teachers struggle to effectively identify, conceptualize, and teach controversial topics in Social Sciences. Nganga et al. (2020, p. 78) further argued that teacher education programs "... do not explicitly develop or recognize the discursive and explorative methods associated with [the] integration of controversial topics".

Notwithstanding, there is evidence that pre-service teachers around the world are generally positive about their preparedness to teach (Khalid et al., 2017; Mayer et al., 2017). Still, there are exceptions in some domains, warranting a need for improvement (Botha \& Reddy, 2011; Stahl et al., 2016). Notable is that contextual realities impose a variety of experiences on teacher education institutions and pre-service teachers alike.

Final year pre-service teachers are most confident to teach when they possess the required content knowledge (Hudson, 2011; Nganga et al., 2020). Effective teachers are expected to possess a wealth of content knowledge, and to have a good theoretical base and good pedagogical and instructional strategies (Cochran-Smith \& Lytle, 1999). These characteristics are possible based on individual teacher education programs. Pre-service Geography teachers, for example, are more likely to accumulate enough content knowledge and develop the confidence to teach geographical skills if they are opportune to attend an institution that provides for them the opportunity to complete many disciplinespecific courses in Geography (Harte \& Reitano, 2015). Effective pre-service Geography teachers therefore need to possess a good understanding of key concepts such as map reading and physical geography (Harte \& Reitano, 2015).

Various means, including reflections, can be used to gather information concerning the quality of any teacher preparation program from pre-service 
teachers (Tatto \& Pippin, 2017). This approach engages pre-service teachers through reflections to deeply interrogate their knowledge base and expertise, their preparedness and readiness to face the teaching profession (Cochran-Smith \& Lytle, 1999). For example, in a study conducted by Harte and Reitano (2015), participating pre-service teachers noted that although they had completed Geography courses in school, it was merely composed of knowledge that can give them a foundation to cope with Geography in the teacher education program. Therefore, they needed more content courses in Geography during the teacher preparation program to enable them to teach effectively after graduation. According to these pre-service teachers, the content knowledge acquired in school is almost irrelevant for two reasons: 1) the duration between when they completed the Geography modules in school and university, and 2) the nature and approach to Geography at the university which is now different as taught in school. To keep pre-service Social Sciences teachers abreast with the changing content and pedagogical practices, more content courses need to be completed for History and Geography at the university.

This explains why Harte and Reitano (2015) argued that pre-service teachers who have completed nine or more Geography-discipline-related courses were more confident to teach Geography than those who have completed fewer courses. According to Tambyah (2008), it is not uncommon for pre-service and novice Social Sciences teachers to lack disciplinary knowledge. For example, Geography teachers are expected to possess adequate content knowledge in human and physical geography. Nonetheless, courses offered by the selected university to pre-service Social Sciences teachers in Geography are more inclined toward human than physical geography (see Table 1). This validates the need to explore how the gap between expectations of trained pre-service Social Sciences teachers and the courses the university offers impacts on their teacher preparation program. The common rhetorical question likely to resonate is whether pre-service Social Sciences teachers in South Africa are sufficiently equipped with content knowledge for core subjects (History and Geography) upon graduation. The emphasis on pre-service Social Sciences teachers in this study derives from the fact that the social sciences provide an important platform for teachers to change learners' educational experiences from a broader perspective (Kenna \& Poole, 2017). The Department of Basic Education (DBE, 2011, p. 8) argued that:

"The subject Social Sciences consist [sic] of History and Geography ... The Social Sciences curriculum aims to provide opportunities for learners to look at their world with fresh, critical eyes and perhaps more importantly, it aims to introduce learners to a world beyond their everyday realities."

The importance attached to Social Sciences explains why engaging pre-service Social Sciences teachers to understand their preparedness and readiness during their training and ability to teach after graduation is relevant. The paper therefore pursues the following question: What factors influence pre-service Social Science teachers' preparedness, readiness, and ability to teach effectively upon graduation? 


\section{Theoretical Framework}

Gibbs' experimental learning cycle which hinges on a six-stage reflective cycle underpins this paper. The cycle provides a structure to analyze a situation (see Figure 1). Gibbs' reflective cycle has been used extensively in the health sciences (Ardian et al., 2019; Li et al., 2020) and other disciplines, including education. For example, Markkanen et al. (2020) used the cycle in Finnish school research aimed at upskilling teachers' ability to deal with challenging situations, enabling teachers to intensively reflect on their learning. Gibbs' ideology, developed in 1988, emanated from the experimental cycle of David Kolb (Gibbs, 1988). The cycle allows for teaching and learning experiences and outcomes to be revealed through debriefings using interviews and questionnaires (Gibbs, 1988). In the view of Gibbs, the cycle can potentially contribute to locating the supposed relationship between educational theories and practice. Hence, it is a perfect tool to understand the preparedness and readiness of pre-service teachers. The focus in this study is pre-service Social Sciences teachers.

Seemingly, learning opportunities become more relevant if experiences are reflected upon (Gibbs, 1988). Feelings and thoughts are shared during reflection to create room for the amelioration of any existing deficiency. For example, when pre-service teachers reflect about what is learnt in relation to future practical experiences as professional teachers, they may identify alignments and misalignments. According to Gibbs, humans add value to themselves when they think about what they do. Hence, learning is not only articulated best when done by doing but also better when reflected upon to understand its successes and challenges (Gibbs, 1988). Reflections produce accurate results, however, when questions used for that purpose are correctly framed. The power of reflection reinforced our decision to engage pre-service Social Sciences teachers in their final year of study to reflect on their teacher education preparation using open-ended questions.

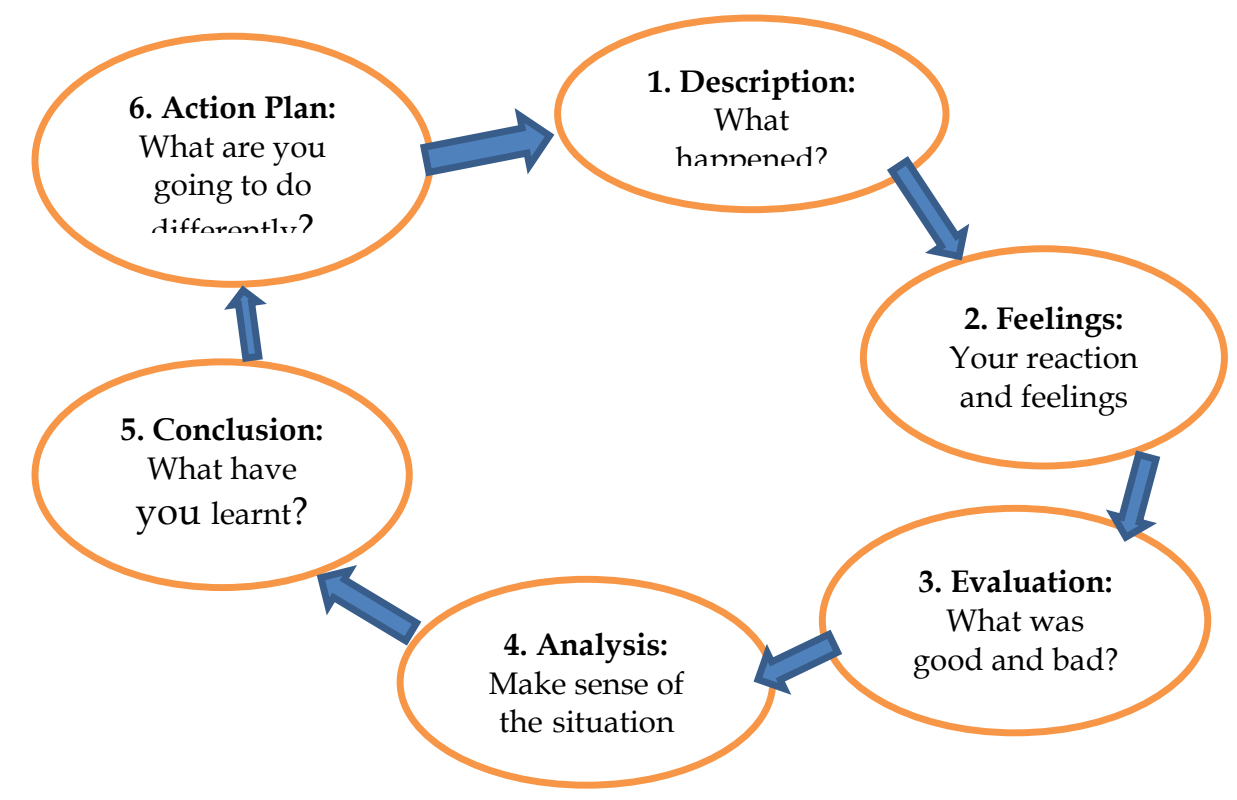

Figure 1: Reflective cycle. Adapted from Gibbs (1988, pp. 49-50) 
Using Gibbs' reflective cycle, Ditchburn (2015) demonstrated that when pre-service teachers constantly reflect on their professional experiences, they are likely to understand the complexities of teaching and learning better. Jang (2019) also used Gibbs' reflective cycle in a pre-service-teacher preparation program with an emphasis on their technological pedagogical content knowledge. Similarly, Ismail and Çavuşoğlu (2017) contended that reflection serves as both an educational and transformational instrument amongst pre-service teachers as the disjuncture between theory and practice is deciphered.

Likewise, Mazzola (2019), using Gibbs' reflective cycle, argued that reflection can potentially bridge the gap between passive and active learning in higher education since it provides an opportunity for pre-service teachers to immerse themselves deeper into what they do. In this paper, we use reflection to understand what a teacher preparation program offers pre-service Social Sciences teachers and how that aligns with their expectations and articulation of their skills in the classroom. The power of reflection portrayed by authors such as Ditchburn (2015), Jang (2019), Ismail and Çavuşoğlu (2017) and Mazzola (2019), further justified its use in this study which focuses on pre-service Social Sciences teachers' reflections on a four-year teacher preparation program.

\section{Methodology}

This qualitative case study aims to understand the perceptions of pre-service Social Sciences teachers on a four-year teacher preparation program through reflections guided by open-ended questions. The qualitative method was chosen to allow participants to express themselves in their own words, void of restrictions. This explains why certain themes that were not preempted emerged from the reflections. Nineteen fourth year pre-service Social Sciences teachers, who were part of the 2020 cohort in a South African public university, participated. They participated voluntarily (McLain \& Kim, 2018) by responding to open-ended questions concerning their preparedness and readiness to teach in future. The research project, which took place in 2020, comprised two phases. The first phase was between 10 February 2020 and 9 March 2020 and the second phase occurred in July 2020. The second phase, which was necessitated by COVID-19, was meant to understand the impact of the pandemic on pre-service teachers' preparedness and readiness based on its negative educational implications across the globe. Since some challenges were raised during the first phase, it became important to do a follow-up to understand whether COVID-19 had exacerbated already existing challenges, thus with additional negative implications on the participants' teacher preparation program. Lockdown in South Africa, like in other countries around the world, led to the introduction of online learning, with numerous challenges for individual students based on context and circumstances. Student participants 1-10 were interviewed during phase one and 11-19 during phase two.

During the data gathering process, questionnaires were administered on Blackboard for all interested final year Social Sciences students to participate, and 19 of them responded to the open-ended questions that were provided. Since it was not a compulsory exercise, only those students who submitted completed sheets of the open-ended questions were considered to ensure that no one 
participated under duress. The aim was to obtain a detailed understanding of concerns that emerged during an impromptu discussion during a lecture that interrogated their preparedness to teach after graduation in 2021.

A thematic method was employed during data analysis. The data were manually coded. This process included reading and rereading responses provided by the pre-service teachers who participated for divergence and convergence. The available data were then shifted to identify valuable information which was arranged into themes. When data from various participants were placed into themes for the first time, a need arose for merging of some themes to avoid duplication and oversimplicity. The mergence gave rise to four main themes.

To ensure that information obtained from the participants was valid and credible, they were asked not to include their names and any other identifiers on the response sheets. Anonymity excludes the fear of victimization and the probability for participants to be genuine in their responses (Pietilä et al., 2020). Also, participating students were informed of their rights and the purpose of the research. In terms of rights, participants were informed that the exercise would not be graded and that there would be no penalties for not participating. Permission to conduct the research was provided by the ethics committee of the selected university.

\subsection{Contextualizing the study}

The study emanated from concerns raised by final year students during classroom discussions meant to talk about their experiences accrued during the first lap of their teaching practice. The discussions produced varied challenges encountered by the participants, which included their inability to adequately engage with content knowledge in core subjects, including History and Geography, during teaching practice. Hence, there is a need to engage them formally and earnestly to better understand their challenges and initiate ways to navigate them to ensure the preparation of proficient professional teachers in future.

\section{Findings and Discussion}

The findings of the study indicated that although the participants presented varying views and opinions regarding the teacher preparation program, emanating from existing challenges, the kind of tuition and guidance received, and their level of preparedness, there was unanimity that content knowledge received in core subjects was inadequate. This has not, however, diluted their enthusiasm to become professional teachers. Four major themes emerged from the study: (i) challenges related to Social Sciences content knowledge in core subjects, (ii) academic advising, (iii) pre-service-teacher preparedness and readiness to teach, and (iv) the implications of COVID-19 on pre-service teachers' readiness and preparedness to teach.

\subsection{Challenges related to content knowledge in core subjects}

Findings suggested that participants received limited content knowledge in core Social Sciences subjects (Geography and History), with implications on their ability to teach. This is corroborated by Kenna and Poole (2017), who explained that teachers who lack content knowledge are generally ill-prepared and, in some 
cases, demotivated to teach. For example, Participants 1, 5, and 10 expected to be taught content knowledge in the core subjects throughout their four years at the university. They argued that although they had received content knowledge in these core subjects whilst in school, this was insufficient and could no longer serve the purpose because, over the years, a lot had changed in depth and breadth of these subjects, a view supported by Harte and Reitano (2015). Hence, the participating pre-service teachers decried the fact that content knowledge in core subjects was neglected as more tuition time was accorded to the learning of teaching methods. However, there was a divided opinion concerning the amount of tuition they received in each of these subjects. For instance, Participants 3, 7, and 8 argued that enough content knowledge was received in History as opposed to Geography. In agreement, P10 said: "I think that I have been adequately prepared as a Social Science teacher... I have been trained in History content as well as teaching techniques ...." There is a correlation between the claims of the participants regarding the nature of tuition received in Social Sciences and what is obtained in the university's faculty rulebook for 2020. A snapshot of this correlation is available in Table 1.

Contrary to the views of other participants, P1, however, claimed that content was never taught: "I did not get enough training as a student-teacher ... since my first year, my lecturers never taught me Geography content ... we never did map skills, physical geography ... We only received enough content on sub-field of Geography ...." Judging from Table 1, the claims of P1 can be interpreted as the participant not having received enough tuition in physical geography leading to a loss of confidence to teach Geography effectively. This is also obtained from the disjuncture between the various specializations offered in Social Sciences at the university (see Table 1) and what the DBE expects from Social Sciences teachers in schools (see page 5). In participants' views, content-knowledge deficiency hindered them from effectively teaching during teaching practice, considering that Social Sciences teachers are expected to be knowledgeable in History and Geography (DBE, 2011). In support of this finding, Harte and Reitano (2015) argued that Geography teachers in training should be well grounded in both physical and human geography to ensure effective teaching and learning. What emerges from the concerns of P1 is that pre-service teachers who do not have a deeper understanding of content knowledge are likely to be discouraged in the classroom, a view shared by Kenna and Poole (2017). Drawing from a Caribbean experience, Robinson (2017) considered content knowledge as a vital tool every teacher needs in the classroom, the lack of which could potentially lead to low levels of learner performance.

The disjuncture between school curriculum and university-course curriculum explains why P1 struggled to teach during teaching practice, a thought shared by P5. Similarly, P8 expounded by saying that, "I did not get enough training in Geography. We have not been taught Geography in depth, but we are expected to teach Geography at school during teaching practical and it is difficult for us to teach." Hudson (2011) and Nganga et al. (2020) agreed that teachers who do not possess adequate content knowledge are not confident enough to teach. However, they can possess deeper content knowledge that is not necessarily aligned with the school curriculum. 
Table 1: Specializations and year courses at the selected university

\begin{tabular}{|c|c|c|c|c|}
\hline $\begin{array}{l}\text { Specialization \& } \\
\text { Courses }\end{array}$ & Year 1 & Year 2 & Year 3 & Year 4 \\
\hline $\begin{array}{l}\text { Life Skills, Social } \\
\text { Sciences \& } \\
\text { Afrikaans First } \\
\text { Additional } \\
\text { Language }\end{array}$ & $\mathrm{N} / \mathrm{A}$ & $\begin{array}{l}\text { Social Sciences } \\
\text { 1: History. } \\
\text { Social Sciences } \\
\text { 2: Geography }\end{array}$ & $\begin{array}{l}\text { Teaching of } \\
\text { Social } \\
\text { Sciences } 1 .\end{array}$ & $\begin{array}{l}\text { Teaching of } \\
\text { Social } \\
\text { Sciences } 1\end{array}$ \\
\hline $\begin{array}{l}\text { Specialising in Life } \\
\text { Skills \& Social } \\
\text { Sciences (LSSS) \& } \\
\text { Sesotho Home } \\
\text { Language }\end{array}$ & N/A & $\begin{array}{l}\text { Social } \\
\text { Sciences 1: } \\
\text { History. } \\
\text { Social } \\
\text { Sciences 2: } \\
\text { Geography. }\end{array}$ & $\begin{array}{l}\text { Teaching of } \\
\text { Social } \\
\text { Sciences } 1 .\end{array}$ & $\begin{array}{l}\text { Teaching of } \\
\text { Social } \\
\text { Sciences } 2 .\end{array}$ \\
\hline $\begin{array}{l}\text { Specialising in Life } \\
\text { Skills, Social } \\
\text { Sciences \& Sesotho } \\
\text { First Additional } \\
\text { Language }\end{array}$ & $\mathrm{N} / \mathrm{A}$ & $\begin{array}{l}\text { Social } \\
\text { Sciences 1: } \\
\text { History. } \\
\text { Social } \\
\text { Sciences 2: } \\
\text { Geography. }\end{array}$ & $\begin{array}{l}\text { Teaching of } \\
\text { Social } \\
\text { Sciences } 1 .\end{array}$ & $\begin{array}{l}\text { Teaching of } \\
\text { Social } \\
\text { Sciences } 2 .\end{array}$ \\
\hline $\begin{array}{l}\text { History and Social } \\
\text { Sciences (HSS) } \\
\text { Specialisations } \\
\text { Specialising in Life } \\
\text { Orientation and } \\
\text { Geography }\end{array}$ & $\begin{array}{l}\text { Introduction to } \\
\text { Geography }\end{array}$ & $\begin{array}{l}\text { Housing and } \\
\text { Urban } \\
\text { Development. } \\
\text { Environment } \\
\text { and Climate. }\end{array}$ & $\begin{array}{l}\text { Geography } \\
\text { Teaching } 1 .\end{array}$ & $\begin{array}{l}\text { Geography } \\
\text { Teaching } 2\end{array}$ \\
\hline $\begin{array}{l}\text { History } \\
\text { And Social } \\
\text { Sciences (HSS) } \\
\text { Specialising in } \\
\text { History and } \\
\text { Geography }\end{array}$ & $\begin{array}{l}\text { Introduction to } \\
\text { Physical } \\
\text { Geography. } \\
\text { Introduction to } \\
\text { the 20th } \\
\text { Century } \\
\text { History of } \\
\text { South Africa. } \\
\text { 20th Century } \\
\text { World History }\end{array}$ & $\begin{array}{l}\text { Housing and } \\
\text { Urban } \\
\text { Development. } \\
\text { The Rise of } \\
\text { Nationalism in } \\
\text { South Africa } \\
\text { (HIST2614). } \\
\text { Environment } \\
\text { and Climate } \\
\text { Studies. } \\
\text { The Rise of } \\
\text { Nationalism in } \\
\text { South Africa } \\
\text { (HIST2624). }\end{array}$ & $\begin{array}{l}\text { Geography } \\
\text { Teaching } 1 . \\
\text { History } \\
\text { Teaching } 1 .\end{array}$ & $\begin{array}{l}\text { Geography } \\
\text { Teaching } 2 . \\
\text { History } \\
\text { Teaching } 2 .\end{array}$ \\
\hline
\end{tabular}

Adapted from selected university's Faculty of Education Rulebook (2020, pp. 124-135, 156-163). 
However, some participant responses somewhat question pre-service teachers' understanding of what constitutes Social Sciences. For example, P6 confidently said:

I have been adequately prepared as a Social Sciences teacher in its entirety ... I'm able to accommodate the learners in the classroom ... I feel relatively confident going into the teaching practice with the training that I have received this far in the content of the core subject of History ....

P6 made a comparison between tuition received in History and Geography, emphasizing a deficiency in Geography content. The excerpt from P6 questions the relationship between what schools expect of Social Sciences teachers and what knowledge institutions provide to prepare these teachers. According to the DBE (2011), Social Sciences comprises History and Geography; hence, all pre-service Social Sciences teachers on teaching practice are expected by schools to teach both subjects effectively. This has placed many Social Sciences teachers in a dilemma. Similarly, P4 observed that content knowledge in core subjects were taught throughout the four years of the teacher preparation program, questioning students' ability to differentiate between pedagogical and content knowledge. Based on these varied perceptions, it is important to interrogate academic advising, a gatekeeper in terms of student teachers' specialty, especially in Social Sciences, during the teacher preparation program at the selected university.

\subsection{Academic advising}

Academic advising is meant to guide students on modules related to specific specialties. Findings showed a divided perception concerning the services provided by academic advisors and its impact on participants' overall preparation. Some participants maintained that academic advising was available and useful, with Participants 2, 4, 6, and 5 being positive toward the services of academic advisors. For example, P2 said: "I got academic advising in my first year; they told me which modules to register for." Similarly, P4 said: "I always go to academic advising and I find it to be very useful." P6 added: "I did receive academic advice concerning which subjects I needed to register and do in order to qualify as a Social Science teacher." Additionally, P5 accessed relevant information beyond academic advising: "In the first year, I got academic advice on which subjects I needed to take. Each year, I refer to the Faculty Rulebook if I am uncertain."

The positive perceptions enumerated toward the services of academic advisors explain why P9 decried that the challenges they encountered were more due to lecturers focusing more on what is convenient for them to teach, many being History specialists who are expected by the university to teach Geography modules. P9 explained:

The academic advisor told me about the modules that I had to register every year in order to qualify to be a Social Science teacher... I think that most of the time, lecturers teach what they are best in and that becomes a challenge ... I can say that I understand History more than Geography, which makes me bias towards Geography.

Furthermore, other participants argued that academic advising was either inadequate or misleading. P10 cautiously elucidated: 
... I received academic advice that informed me that Geography modules would not be a necessary requirement to qualify as a Social Science teacher. As such, I only completed History modules ... I feel somewhat nervous about teaching a Geography lesson given my lack of knowledge or training on the subject ... I didn't take Geography lessons during my time at the university based on the academic advice that I received. My nervousness can't and shouldn't reflect the training the university offers.

The assertion of P10 does not portray academic advisors as incompetent but aligns more with how Social Sciences specialties are designed at the university, often derailing from what is expected in schools. This aligns with the view of Tatto and Pippin (2017) that contextual realities significantly influence the quality of teachers in individual spaces across the globe. This also attests Tambyah's (2008) notion that a clear understanding of what constitutes pre-service teachers' content knowledge in some teacher education programs across the globe is problematic. P10 particularly questioned the delimitation of Social Sciences content knowledge at the university that contradicts what schools expect of pre-service Social Sciences teachers. To deduce from P10's narrative that the responsible academic advisor lacked certain professional and educational skills in their informing of pre-service teachers (McGill et al., 2020) is thus contested.

Additionally, in terms of limited academic advising, P8 painted a different picture of events, though with some caution:

I did not get enough academic advice on my first year and just saw myself doing Social Sciences and Life Skills. I also think that the university should allow everyone to choose their specialty, because choosing for us is not working and that is the reason why we find teachers not doing their work ... they are doing or teaching subjects they do not like....

Such perceptions are worth taking note of and attending to because the perceptions of graduate teachers epitomize the quality and value of the institutions that prepared them (Mayer et al., 2017). The existent challenges, coupled with divergent views concerning the services of academic advisors and the implications thereof, raise eyebrows concerning the preparedness and readiness of the participating pre-service Social Sciences teachers, especially because many of them were to begin teaching in 2021.

\subsection{Pre-service teachers' preparedness and readiness to teach}

Despite existing challenges, most of the participants were generally positive and eager to begin their teaching profession in the following year (2021). To begin with, P3 considered their readiness and confidence to teach not optional, irrespective of existing challenges: "We must feel confident; we must learn from the teachers in school how to give classes [lessons] in Geography and History." These thoughts were reechoed by P1, who applauded teaching practice for assisting them to learn more despite not getting enough preparation at the university regardless of much anticipation: "I thought that [during] my fourth year, that's where I will be taught more about History and Geography [content] ... but I taught myself subject knowledge, not the university ...." Similarly, P3 mentioned: "... I feel we learn much more during practical than the knowledge we learn at the university ...." However, 
P2 supposed that much effort was still needed even at individual level to enable them to become the professional teachers they were expected to be: "I am not as prepared as I need to be. I still need to do more research on the content in Social Sciences and gain more knowledge on the subject matter." P9 agreed: "There are still some of the things that I cannot understand ... that I still want to learn or to be taught."

Nevertheless, optimism was vivid in the words of P5:

I believe that by the end of the year [2020], I will be fully equipped to be a Social Science teacher. I believe that my content knowledge of the subject is adequate and that the rest of the year will prepare me well enough to deliver the content effectively from 2021.

Also, worth mentioning is the undiluted eagerness of P8, who said: "I cannot wait to finish my degree and go out there to show the world and learners how to teach Social Sciences and how important social sciences are ...." Such elation does not imply, however, that P8 was adequately prepared for the classroom, as can be deduced from the following words: "The content is different from the one we are supposed to teach ... at school, we are expected to teach about things like mapwork ... we have not been taught about mapwork here ..." Mapwork emerged from the research of Harte and Reitano (2015) as an important prerequisite for effective Geography teachers. Within the Namibian context, Naxweka and Wilmot (2019) argued that when teachers lack the skills to teach mapwork to students, there are likely to be negative implications on their performance. Similarly, P9 commented on the implications of a knowledge gap in the teaching and learning process: "... it becomes difficult to teach learners something that you hardly know ... At some point, I am not good with the strategies to use when I teach Geography and I am not good with mathematics."

Similarly, P3 explained: "In Geography, we only learned about the concepts ... We have also just learned about history and what history is all about ...." It is worth noting that Geography content knowledge received in school is meant to serve as a foundation to enable pre-service teachers to cope with tuition at university, where it is expected that pre-service teachers will be assisted adequately to acquire a deeper understanding of content knowledge. This is because the nature of and approach to Geography at university have changed over time, especially with the advent of technology. Pre-service teachers need to be knowledgeable in both physical and human geography content to effectively teach in the classroom. This aligns with the view of Blankman et al. (2016, p. 425) that many teachers in training are not conversant with the basic concepts of Geography teaching. In a rather concerning tone, P8 expressed ongoing reservations about the level of preparedness: "I have been concerned about the quality of my training before fourth year because I do not know how to produce things that CAPS want us as Social Sciences teachers to produce." Comparable sentiments, although somewhat optimistic, were echoed by P4, who said: "I always questioned if I was ever ready, but as time went on, I worked on my self-confidence and -esteem."

Furthermore, when asked about the ability to teach Geography effectively, P1 expounded: "... I don't have enough subject knowledge. The faculty did not develop me that much." In agreement, P2 added: "We did not really focus on the content that we 
would have to teach when we start teaching. Not much focus was given to Geography; we mostly focus on History." To emphasize the neglect of Geography content knowledge, P9 explained: "What we learned about History was sufficient ... for Geography, it was not sufficient, because I still struggle on how to teach learners maps because I have not been taught ...." The concerns of these participants are supported by Mkhasibe (2018), who reiterated the importance of accumulating enough content knowledge, which determines teachers' ability to teach effectively. For participants such as $\mathrm{P} 8$, the confidence to teach derives from the fact that teaching practice provided a space to accumulate sufficient content knowledge compared to the university: "I feel confident, not because I have received enough training, but because I have been doing teaching practice for the past years ... I interact and communicate with my mentors if there is something I struggle with." Although the assertion of P8 cannot hold true for all pre-service teachers, it does indicate that the context of teaching practice and the mentors involved contribute in shaping pre-service teachers either positively or negatively.

Apart from the challenges, P1 contemplated strategies to overcome existing gaps: The training was not enough ... I lack the subject knowledge of Social Sciences. When I teach Social Sciences, I must rely on the knowledge and skills I developed from high school ... I must do more research and borrow books from the library to develop my History knowledge.

P7, however, was more concerned about pedagogical gaps: "I am nervous about ... 2021 because I am not sure whether the learners will understand me when I present the lesson to them." It should be noted, though, that most of the participants were satisfied with the pedagogical aspect of their training. Despite the positive perceptions participants revealed, numerous challenges obstructed their journey to become professional teachers. Their circumstances were exacerbated by the global implications of COVID-19 on the educational sector.

\subsection{Implications of COVID-19 on pre-service-teacher readiness and preparedness to teach}

The impact of COVID-19 on teacher preparation cannot be denied (Hartshorne et al., 2020). The advent of COVID-19 precipitated an end to face-to-face tuition and the introduction of online learning in South Africa and beyond, with varied implications. It emerged that online learning exacerbated existing challenges faced by the participating pre-service teachers. P13 elucidated as follows:

COVID-19 has had a very negative impact on my teacher preparation program. I am a very practical person; learning online is very difficult for me as I do not have all resources needed to pursue meaningful learning and the submission of tasks and attending of online classes ....

Online assessment is a challenge for students within and beyond the borders of South Africa (Kabir et al., 2021). This explains why P14 indicated preference for face-to-face teaching: "I would have gained more experience in face-to-face lectures rather than online learning." To boost this argument, P11 explained the limited assistance experienced from some lecturers during online learning and its implications: 
Many lecturers have not assisted us ... Some do not properly communicate about assessments and what is expected of us during this time. This has caused confusion and a great deal of stress. I do believe that we have lost valuable time which could have been used to equip us better....

The impression that online learning exposed the inadequacies of many lecturers, especially regarding their communication and technological skills, was reechoed by P16:

COVID-19 has primarily impacted my teacher preparation program by adding a layer of uncertainty with regards to the delivery of content. In some modules, there is limited communication and in others where there is communication, much of it is not clear or concise in its execution. This has established a skeptical perspective on the online teaching and learning experiences in that the competencies of some lecturers are brought into question as it relates to technological proficiency.

Naylor et al. (2015) noted that criticisms toward teacher training institutions are not uncommon and are due to varied reasons. The exacerbation of these challenges during a pandemic such as COVID-19 cannot be overemphasized. P15 supposed that intermittent internet connectivity worsened the situation: "... internet connection is not up to standard ... it takes me longer than it should to do assignments due to my poor internet connection." Internet connectivity is a major challenge for online teaching and learning in South Africa and beyond (Omodan \& Ige, 2021; Paudel, 2021), with students residing in rural communities being the most affected (Molise \& Dube, 2020). Similar thoughts were echoed by P14, who felt demotivated as online teaching worsened existing circumstances: "It has even been very difficult for some of us to learn or acquire knowledge through face-to-face sessions. Some of us are not even motivated anymore because we are losing hope on our studies ..." P12 further explicated the disadvantages of online learning and the implications thereof:

I am used to going to class ... ask questions about something I don't understand.

Now, I must accept everything and make peace with the fact that everything changed. My performance has dropped significantly because of the challenges ... At home, we don't all have ... Wi-Fi or a laptop or even money.

In the view of Itmeizeh and Farrah (2021), learning is likely to be more effective if online learning is combined with some degree of face-to-face interaction between lecturers and students.

Existent challenges were expounded by P17, who expressed uncertainty about their future as professional teachers: “... I could not practice my teaching skills in a school setup ... I have not been able to get into a school ... I am not sure how or when or if I will be getting my degree this year." P18 felt that online learning was overwhelming and psychologically torturing:

COVID-19 has played a lot of mind games with me since the start of lockdown. I kept on feeling lost regarding my studies. I kept on feeling like I missed something or [am] behind with my work because of the lack of communication from some of my lecturers. In some subjects, I am still in the dark and haven't received any form of 
assignments or an activity. The closer we move to the end of the year, the more anxious I get about those subjects where I haven't heard much of.

Worthy to note is that P18 and P15 were adamant that not all lecturers left them in the dark. For example, P18 explicated: "Other subjects I feel confident, thanks to regular communication and activities from the lecturers." In agreement, P15 acknowledged the effort of lecturers who consistently communicated with them, thereby ameliorating the stress of many students.

Generally, some research participants were of the view that despite the negative connotations of online learning, it was unprecedented and had some advantages. For example, P13 gave an honest balance sheet of online teaching in the following words:

I honestly think that there's nothing that could have been done differently ... the university tried its best to keep everything going ... The lecturers and us the students, we tried our best to keep up with the work, but the pandemic was just way above us. There is nothing that could have been done.

Interestingly, P15 described online learning as a learning curve: ... distance learning has prepared me for the real world ... I don't have a lecturer reminding me every time to go to class ... that I have an assignment ... now, as an individual, I need to seek for information without someone always reminding me.

P13 agreed: "Nevertheless, this pandemic has taught me how to work under pressure... taught me to be self-disciplined through difficulties." To debunk negative perceptions toward online learning, P16 said: "Despite the online learning experience being somewhat of a mixed bag, I would not suggest that my preparedness for the teaching profession has been severely impacted ... There are other variables that require consideration, like the availability of technology ...." The congruence of views participants raised about online learning indicates that despite existing challenges there is hope if appropriate measures are put in place.

\section{Conclusion}

The paper focused on the reflections of final year pre-service Social Sciences teachers to understand their preparation using Gibbs' reflective cycle as a lens. After thematic analysis, four themes emerged: challenges related to content knowledge in core subjects, academic advising, pre-service-teacher preparedness and readiness to teach, and implications of COVID-19 on pre-service-teacher readiness and preparedness to teach.

Based on the findings, we recommend that universities should clarify Social Sciences content, specifically History and Geography, in order to align it with DBE expectations and what is applicable in schools. A balanced tuition for content knowledge and pedagogy in Geography and History is imperative. The teaching and learning unit of the Faculty of Education should put in place mechanisms to regularly check whether students are receiving the expected content knowledge. Currently, some challenges exist due to oversight by relevant authorities who ought to revisit what students are taught on a regular basis to intervene where necessary. Such interventions should include ensuring that responsible lecturers 
have relevant qualifications/skills to provide adequate content knowledge to pre-service teachers. Lecturers also require ongoing professional development on remote teaching to improve their communication and technological skills. The varied challenges of online learning warrant the equipping of students with the necessary resources to facilitate learning.

The findings of this research contribute to ongoing discourses on teacher preparation, particularly in South Africa and beyond, and bring to light some challenges pre-service Social Sciences teachers in South Africa encounter due to the nature of training provided. This research is limited because it focused on pre-service Social Sciences teachers in one university in South Africa. Further research in other universities is therefore encouraged for a broader understanding of the experiences of pre-service Social Sciences teachers during their teacher preparation program.

\section{References}

Ardian, P., Hariyati, R. T. S., \& Afifah, E. (2019). Correlation between implementation case reflection discussion based on the Graham Gibbs Cycle and nurses' critical thinking skills. Enfermeria Clinica, 29(2), 588-593. https://doi.org/10.1016/j.enfcli.2019.04.091

Blankman, M., Schoonenboom, J., Van der Schee, J., Boogaard, M., \& Volman, M.

(2016). Learning to teach Geography for primary education: Results of an experimental programme. Journal of Geography in Higher Education, 40(3), 425-441. http://dx.doi.org/10.1080/03098265.2016.1144731

Botha, M. L., \& Reddy, C. P. S. (2011). In-service teachers' perspectives of pre-service teachers' knowledge domains in Science. South African Journal of Education, 31(2), 257-274. https://doi.org/10.15700/saje.v31n2a354

Cochran-Smith, M., \& Lytle, S. I. (1999). Relationships of knowledge and practice: Teacher learning in communities. Review of Research in Education, 24, 249-305. https://doi.org/10.2307/1167272

Department of Basic Education (DBE). (2011). Curriculum and Assessment Policy Statement Grades 7-9: Social Sciences. Cape Town: Government Printing Works.

Ditchburn, G. M. (2015). Remembering reflection in pre-service teachers' professional experience. Australian Journal of Teacher Education, 40(2), 94-111. http://dx.doi.org/10.14221/ajte.2015v40n2.7

Gibbs, G. (1988). Learning by doing: A guide to teaching and learning methods. London: Further Education Unit.

Harte, W., \& Reitano, P. (2015). Pre-service Geography teachers' confidence in geographical subject matter knowledge and teaching geographical skills. International Research in Geographical and Environmental Education, 24(3), 223-236. https://doi.org/10.1080/10382046.2015.1034458

Hartshorne, R., Baumgartner, E., Kaplan-Rakowski, R., Mouza, C., \& Ferdig, R. E. (2020). Special issue editorial: Preservice and inservice professional development during the COVID-19 pandemic. Journal of Technology and Teacher Education, 28(2), 137-147. https://www.learntechlib.org/primary/p/216910/

Hudson, S. (2011). Pre-service teachers' perceptions of their middle schooling teacher preparation: A sample of the Australian context (Doctoral dissertation). Southern Cross University, Australia.

Ismail, A. M., \& Çavuşoğlu, Ç. (2017). Theory into practice: The content of pre-service teachers' reflections in North Cyprus. In I. H. Amzat \& N. P. Valdez (Eds.), Teacher 
empowerment toward professional development and practices (pp. 221-237). Springer Nature. https://doi.org/10.1007/978-981-10-4151-8_15

Itmeizeh, M., \& Farrah, M. (2021). EFL instructors and learners' perceptions towards utilization of online applications at Palestine Ahliya University and Hebron University. Universal Journal of Educational Research, 8(8), 3310-3322. https://doi.org/10.13189/ujer.2021.090201

Jang, J. (2019). Reimagining technology preparation for pre-service teachers: Exploring how the use of a video self-analysis instructional component, based on the evidential reasoning and decision support model, impacts pre-service teachers' technological pedagogical content knowledge (Doctoral dissertation). Syracuse University, NY, United States.

Kabir, M. R., Islam, M. A., \& Deena, S. A. (2021). Explaining the adoption of technologybased design of higher education during and after COVID 19 period from a developing country perspective. Interaction Design and Architecture(s) Journal, 46(2020), 88-119.

Kenna, J. L., \& Poole, C. M. (2017). Social Science pre-service teachers' preparation to teach about Asia: A research study. Journal of Social Studies Education Research, 8(1), 93-114. https://dergipark.org.tr/en/pub/jsser/issue/29488/316359

Khalid, A., Dukmak, S. J., \& Dweikat, F. F. I. (2017). Pre-service teachers' perception of their educational preparation. International Journal for Research in Education, 41(1), 273-303. https:// scholarworks.uaeu.ac.ae/ijre/vol41/iss1/9/

Li, Y., Chen, W., Liu, C., \& Deng, M. (2020). Nurses' psychological feelings about the application of Gibbs reflective cycle of adverse events. American Journal of Nursing, 9(2), 74-78. https://doi.org/10.11648/j.ajns.20200902.17

Markkanen, P., Välimäki, M., Anttila, M., \& Kuuskorpi, M. (2020). A reflective cycle: Understanding challenging situations in a school setting. Educational Research, 62(1), 46-62. https://doi.org/10.1080/00131881.2020.1711790

Mayer, D., Dixon, M., Kline, J., Kostogriz, A., Moss, J., Rowan, L., Walker-Gibbs, B., \& White, S. (2017). Studying the effectiveness of teacher education: Early career teachers in diverse settings. Springer Nature.

Mazzola, C. (2019, March 9). Bridging the gaps between passive and active learning in higher education [Blog post]. http:// blog.cmaz.co.uk/ post.php?id=26

McGill, C. M., Ali, M., \& Barton, D. (2020). Skills and competencies for effective academic advising and personal tutoring. Frontiers in Education, 5, 135. https://doi.org/10.3389/feduc.2020.00135

McLain, C., \& Kim, J. (2018). Ethical issues in qualitative data collection. In C. T. Sibinga (Ed.), Ensuring research integrity and the ethical management of data (pp. 112-126). United States of America: IGI Global. https://doi.org/10.4018/978-1-5225-80577.ch035

Mkhasibe, R. G. N. (2018). Evaluation of pre-service teachers' readiness to teach: A case study of a South African university (Doctoral dissertation). University of Zululand, South Africa).

Molise, H., \& Dube, B. (2020). Emergency online teaching in Economic and Management Sciences necessitated by the COVID-19 pandemic: The need for healthy relations in a rural schooling context. International Journal of Learning, Teaching and Educational Research, 19(6), 387-400. https://doi.org/10.26803/ijlter.19.6.23

Naxweka, J., \& Wilmot, D. (2019). Namibian teachers' perceptions and practices of teaching mapwork. Journal of Geography Education for Southern Africa, 4(2), 39-57. https://doi.org/10.46622/JoGESA_4(2)2019_40-57

Naylor, D., Campbell-Evans, G., \& Maloney, C. (2015). Learning to teach: What do pre-service teachers report. Australian Journal of Teacher Education, 40(11), 120-136. http://dx.doi.org/10.14221/ajte.2015v40n11.7 
Nganga, L., Roberts, A., Kambutu, J., \& James, J. (2020). Examining pre-service teachers' preparedness and perceptions about teaching controversial issues in Social Studies. The Journal of Social Studies Research, 44(1), 77-90. https://doi.org/10.1016/j.jssr.2019.08.001

Omodan, B. I., \& Ige, O. A. (2021). Sustaining collaborative learning among university students in the wake of COVID-19: The perspective of online community project. International Journal of Learning, Teaching and Educational Research, 20(1), 356-371. https://doi.org/10.26803/ijlter.20.1.20

Paudel, P. (2021). Online education: Benefits, challenges and strategies during and after COVID-19 in higher education. International Journal on Studies in Education, 3(2), 70-85. https://doi.org/10.46328/ijonse.32

Petrarca, D., \& Bullock, S. M. (2014). Tensions between theory and practice: Interrogating our pedagogy through collaborative self-study. Professional Development in Education, 40(2), 265-281. https:// doi.org/10.1080/19415257.2013.801876

Pietilä, A. M., Nurmi, S. M., Halkoaho, A., \& Kyngäs, H. (2020). Qualitative research: Ethical considerations. In H. Kyngäs, K. Mikkonen, \& M. Kääriäinen (Eds.), The application of content analysis in nursing science research (pp. 49-69). Switzerland AG: Springer Nature. https:/ / doi.org/10.1007/978-3-030-30199-6_2

Robinson, E. S. (2017). Science content knowledge: A component of teacher effectiveness in a primary school in Jamaica (Doctoral thesis). Walden University, United States of America.

Stahl, G., Sharplin, E., \& Kehrwald, B. (2016). Developing pre-service teachers' confidence: Real-time coaching in teacher education. Reflective Practice, 17(6), 724-738. https://doi.org/10.1080/14623943.2016.1206882

Tambyah, M. (2008). Will they know enough? Pre-service primary teachers' knowledge base for teaching Integrated Social Sciences. Australian Journal of Teacher Education, 33(6), 44-60. http://dx.doi.org/10.14221/ajte.2008v33n6.4

Tatto, M. T., \& Pippin, J. (2017). The quest for quality and the rise of accountability in teacher education. In D. J. Clandinin, \& J. Husu (Eds.), The Sage handbook of research on teacher education (pp. 68-89). Sage. https:// doi.org/10.4135/9781526402042.n4 